\title{
Meso-Neoarchean Key Magmatic Systems from Karelian Craton: Geochemical Characteristics and Geodynamic Implication
}

\author{
Svetov $\mathrm{SA}^{1 *}$, Singh $\mathrm{VK}^{2}$, Chazengina $\mathrm{SY}^{1}$, Rybnikova $\mathrm{ZP}^{1}$ and Gogolev $\mathrm{MA}^{1}$ \\ 1Institute of Geology Karelian Research Centre RAS, Russia \\ 2Department of Geology, Bundelkhand University, India \\ *Corresponding author: Svetov SA, Institute of Geology Karelian Research Centre RAS, Pushkinskaja, Petrozavodsk, Karelia, Russia
}

Submission: 㘹 July 02, 2018; Published: 㘹 September 20, 2018

\begin{abstract}
The rock assemblages of the Vedlozero-Segozero greenstone belt (Central Karelia) were used as reference pattern for the study of Archean crustforming processes of the Karelian Craton. This paper presents geochemical and U-Pb (SHRIMP II) zircon dating data for the mafic and andesite rocks. The results obtained by using the approach, based on the analysis of the volcanic rocks, combined with intrusive and sedimentary rocks, maintain the model of the initial stage of the assembling of the Karelian Craton.
\end{abstract}

Keywords: Magmatic systems; Archean; Karelia craton; Komatiite; Adakite

\section{Introduction}

The reconstruction of the formation conditions, architecture and mineralogical composition of the early lithosphere is a key problem in modern geology. A number of studies indicates that the geodynamic evolution models of Meso and Neoarchean associations in the various regions of the Earth have both similar features with the Phanerozoic systems, described within the framework of the interaction of lithospheric plate tectonics and mantle plumes [13] and principal differences caused by the evolution of the Earth's thermal regime $[4,5]$.

One of the opportunities to reconstruct the mechanism of Archean craton assembling is analysis of magmatic systems of Green-Stone Belts (GSB), well or partially preserved in the many Archean cratons. The most abundant magmatic systems of Archean are the komatiite -basalt and andesite - dacite - rhyolite systems. It is noteworthy the coexistence of geochemical contract series within the single system. For example, the Archean mafic rocks are represented by the variety of komatiitic, tholeiitic and Island-Arc Tholeiitic (IAT) assemblages [6,7]. The felsic rock series comprise Adakite (A), Basalt- Andesite- Dacite- Rhyolite (BADR), AndesiteDacite- Rhyolite (ADR), tholeiite (TA), Bajaites (B), and high Nbbasalts (HNB) assemblages [2].

The evolution model of the early crust for the Karelian Craton is based on the estimation of the petrological condition of magma generation and geodynamic regimes of the initiation of magmatic systems. The most suitable area for such studies is the western flank of the Paleoarchean Vodlozero Block (Central Karelia), particularly the Vedlozero-Segozero greenstone belt, where all MesoNeoarchean igneous events are manifested in a local scale $[8,9]$. This paper presents newly obtained geochemical and U-Pb (SHRIMP II) zircon dating data for the rocks from the Vedlozero-Segozero greenstone belt. These studies were carried out to investigate the volcanic rocks, together with the intrusive and sedimentary rocks of the Vedlozero-Segozero greenstone belt. This «triad» approach allows distinguishing a variety of magmatic systems and provides insight in the Archean crust-forming processes.

\section{Geological Setting}

The Vedlozero-Segozero greenstone belt GSB is located in the central part of the Karelian Craton and extends in sub-meridian direction over a distance of approximately $300 \mathrm{~km}$ and has a width of 50-60km (Figure 1). It consists of several local domains including Khautavaara, Koikary, Palasel'ga, Maselga, Semch, Sovdozero, and Oster [10] in which the series of volcano-sedimentary rocks with the maximum thickness up to $6 \mathrm{~km}$ occur within the Neoarchean granitoid rocks. The distinctive feature of these domains is the good preservation of the rock texture despite the rocks were affected by greenschist- to epidote amphibolite-facies regional metamorphism of the andalusite-sillimanite type at a pressure of ca. 2-4k bar and temperature of lower than $540{ }^{\circ} \mathrm{C}$ [11]. On the contrary, in the Vodlozero Block the tonalite-trondhjemite-granodiorite (TTG) rocks are observed at only few outcrops (Figure 2a). 


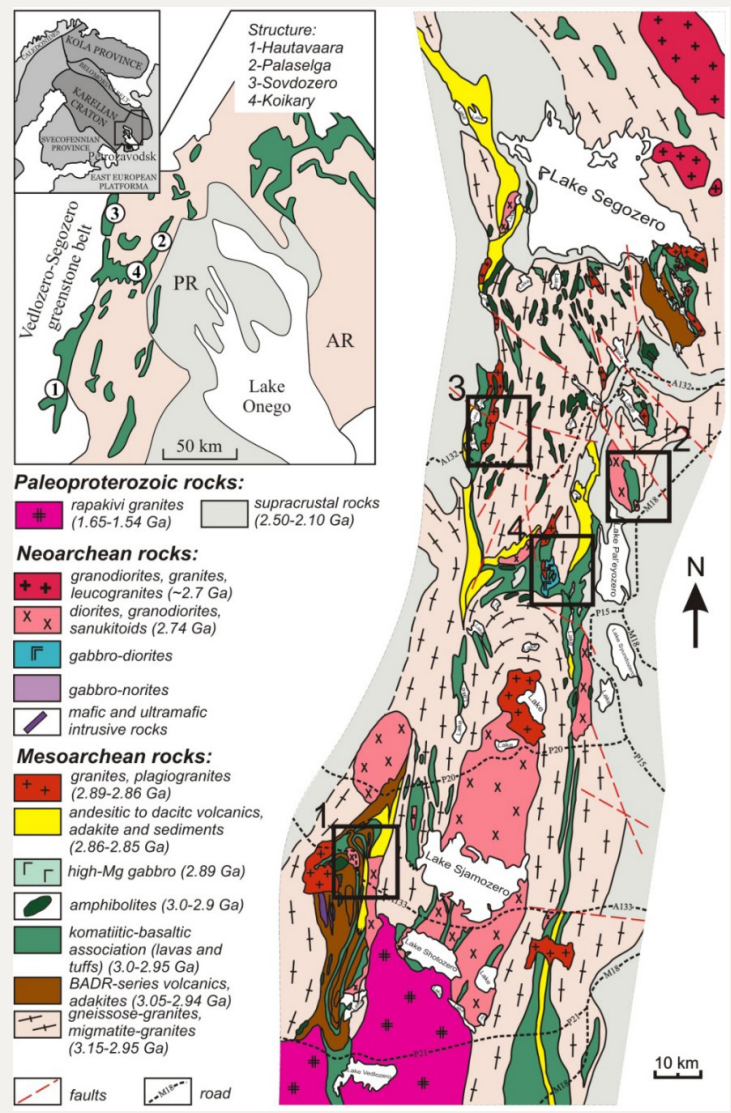

Figure 1: Geological map of the Vedlozero Segozero greenstone belt [8].
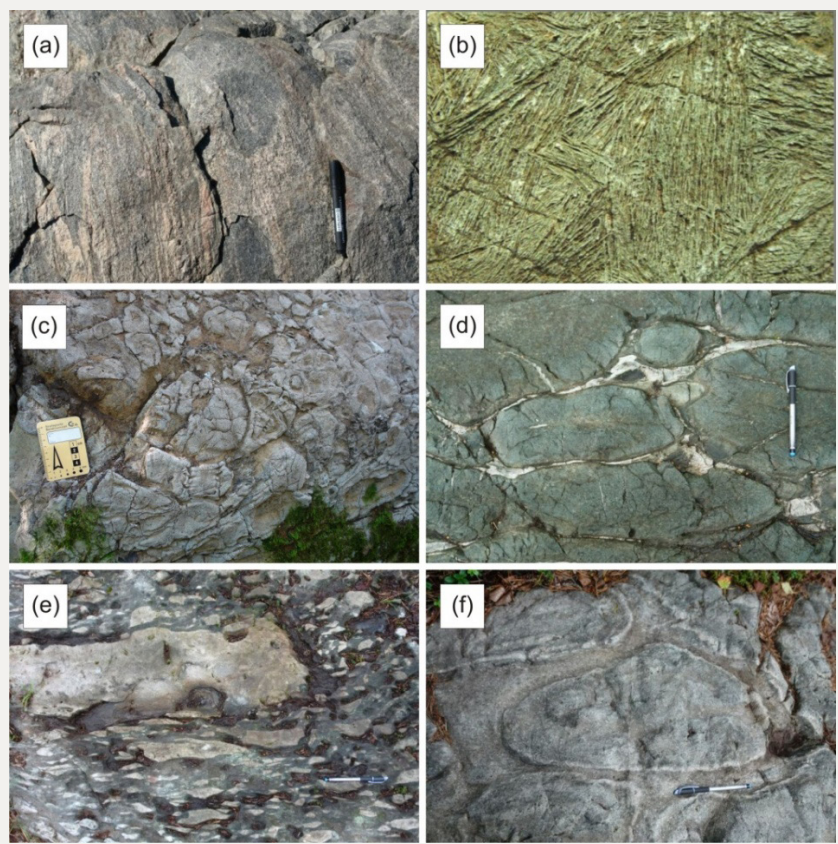

Figure 2: Photographs showing typical features and field occurrence.

Figure 2a: Tonalite-trondhjemite-granodiorite (TTG) from the Vodlozero Block (3.2Ga).

Figure 2b: Komatiitic lava flow with spinifex texture from the Sovdozero domain.

Figure 2c: Lava breccia of komatiite from the Sovdozero domain.

Figure 2d: Pillow lava of komatiite from the Koikary domain.

Figure 2e: Agglomerate tuff of andesite from the Chalka domain.

Figure 2f: Pillow lava of andesite porphyrite from the Chalka domain. 


\section{Methods}

The paper presents the data on the chemical analysis of bulk rock composition conducted in the Analytical Centre of Institute of Geology, Karelian Research Centre, RAS. The concentrations ofmajor oxides were determined by quantitative chemical analysis. Analyses were carried out with uncertainties of $1-5 \mathrm{rel} \%$ for elements with concentrations more than $0.5 \mathrm{wt} \%$ and up to $12 \mathrm{rel} . \%$ for elements with concentrations less than $0.5 \mathrm{wt} \%$. The minor and trace element contents were determined by ICP-MS on a Thermo Scientific X Series 2 instrument, using conventional technique [12]. $\mathrm{U}-\mathrm{Pb}$ isotopic studies of zircon were carried out using a SHRIMPII ion microprobe at the Center for Isotopic Research, Karpinskii All-Russia Research Institute of Geology (St. Petersburg) using standard technique $[13,14]$.

\section{Results}

\section{Komatiite-basalt magmatic system}

Mesoarchean mafic rocks (komatiite-basalt series) from the Vedlozero-Segozero GSB are represented by the rock series with reconstructed thickness up to $2 \mathrm{~km}$. Komatiites with $\mathrm{MgO}$ content ca. $18-26$ wt.\% form a succession of lava flows ca. $50-600 \mathrm{~m}$ in thickness.

The komatiite-basalts consist of strata-bound rock sequences, composed of pillowed, massive and variolitic differentiated lavas with spinifex texture, lava breccia (Figure 2b-2d) together with tuff and sedimentary rock beds and intrusive dunite-peridotite and Mg-rich gabbro bodies. The studied sequence in mafic series is considered to be the result of collage of separate basaltic plates that supposed the idea that the primary series of mafic rocks did not exceed $1.5 \mathrm{~km}$.

Tectonic displacement of the basaltic plates is marked by the occurrence of greywacke in the volcanic mafic rock series, which originated from the destruction of komatiitic rocks. The time of mafic rock formation from the Vedlozero-Segozero GSB reasonably assumed to be discrete. The data provided by Arestova et al. [9] indicate, that the age of the gabbroid rocks of Palaselga domain based on U-Pb (SHRIMP II) dating of zircon is 3.02-2.96Ga. The present data show, that the age of mafic complexes from Koikary and Hautavaara domains is slightly younger.

The age of komatiites from Koikary domain based on U-Pb (SHRIMP II) dating of zircons from dacite dykes, which crosscut the komatiites, is $3.00-2.93 \mathrm{Ga}$. The age of komatiites from Hautavaara domain determined by U-Pb (SHRIMP II) dating of detrital zircons in greywacke interlayered between the komatiitic lava flows is 2.92-2.91. These results argue strongly to multi-stage model of mafic series formation. Regarding chemical composition, the following types of mafic rocks from the Vedlozero-Segozero GSB have been distinguished:

1. Komatiites of Al-undepleted uncontaminated type (AUDK-UC) with the contents of $\mathrm{SiO}_{2}<43 \mathrm{wt} . \%$ and $\mathrm{MgO}>18 \mathrm{wt}$.\%. It is characterized by the ratios $\mathrm{CaO} / \mathrm{Al}_{2} \mathrm{O}_{3}<1(0.4-1), \mathrm{Al}_{2} \mathrm{O}_{3} / \mathrm{TiO}_{2} \approx 22$
$(14-25),(\mathrm{La} / \mathrm{Sm})_{\mathrm{n}}=0.4-1.1$ and $(\mathrm{Gd} / \mathrm{Yb})_{\mathrm{n}}=0.9-1$.

2. Komatiites of Al-depleted contaminated type (AUDK-C) with the contents of $43<\mathrm{SiO}_{2}<50 \mathrm{wt} . \%$ and $\mathrm{MgO}>18 \mathrm{wt} . \%$. It is characterized by the ratios $\mathrm{CaO} / \mathrm{Al}_{2} \mathrm{O}_{3}<1(0.4-1.2), \mathrm{Al}_{2} \mathrm{O}_{3} / \mathrm{TiO}_{2} \approx 22$ $(19-26),(\mathrm{La} / \mathrm{Sm})_{\mathrm{n}}=1 \cdot 1-4 \cdot 2$, and $(\mathrm{Gd} / \mathrm{Yb})_{\mathrm{n}}=0.8-1.3$.

3. Komatiitic basalts (KB) with the $\mathrm{SiO}_{2}$ contents from 44 to $52 \mathrm{wt} . \%$ and $\mathrm{MgO}$ content from 6 to $18 \mathrm{wt} . \%$. It is characterized by the ratios $\mathrm{CaO} / \mathrm{Al}_{2} \mathrm{O}_{3}<1$ (ca. 0.5-0.7), $\mathrm{Al}_{2} \mathrm{O}_{3} / \mathrm{TiO}_{2} \approx 20$ (ca. 17-25), $(\mathrm{La} / \mathrm{Sm})_{\mathrm{n}}=0.3-0.7$, and $(\mathrm{Gd} / \mathrm{Yb})_{\mathrm{n}}=0.7-1.0$.

4. Tholeiitic basalts (MORB) with the contents of $46<\mathrm{SiO}_{2}<50 \mathrm{wt} . \%$ and $6<\mathrm{MgO}<10 \mathrm{wt}$. $\%$. It is characterized by the ratios $\mathrm{CaO} / \mathrm{Al}_{2} \mathrm{O}_{3}<1 \quad(0.5-0.8), \mathrm{Al}_{2} \mathrm{O}_{3} / \mathrm{TiO}_{2} \approx 40$ (30-50), (La/Sm) $\mathrm{n}=0.1-0.4$, and $(\mathrm{Gd} / \mathrm{Yb})_{\mathrm{n}}=0.7-3.0$.

5. Island-arc tholeiitic basalts and andesite-basalts (IAT) with $46<\mathrm{SiO}_{2}<57 \mathrm{wt}$. \%, $2<\mathrm{MgO}<10 \mathrm{wt} . \%, \mathrm{CaO} / \mathrm{Al}_{2} \mathrm{O}_{3}<1(0.5-0.7)$, $\mathrm{Al}_{2} \mathrm{O}_{3} / \mathrm{TiO}_{2} \approx 25$ (18-35), $(\mathrm{La} / \mathrm{Sm})_{\mathrm{n}}=0.1-0.2$, and $(\mathrm{Gd} / \mathrm{Yb})_{\mathrm{n}}=2.1-$ 4.0. These rocks are characterized by the content of La>15ppm, $\mathrm{Ce}>30 \mathrm{ppm}, \mathrm{Rb}$ 20-80ppm, and Ba 30-200ppm. Their composition is enriched in LREE and depleted in Ti, $\mathrm{Nb}$, and Ta.

Intrusive rocks, that are comagmatic to the mafic volcanic rocks from the Vedlozero-Segozero GSB, are represented by duniteperidotite (chemical analogues of komatiite of AUDK-C type) and Mg-rich gabbro (chemical analogues of the IAT type) rocks. The sedimentary rocks associated with the studied Meso-Neoarchean mafic complexes have the litho-geochemical characteristics similar to the sedimentary sequences from Phanerozoic ophiolites complexes $[15,16]$. They are represented by mafic tuffs and tuffites, silicites and siltstones, which are enriched in clay, organic matter, silica, iron and sulphur, and associated with exhalativehydrothermal removals.

\section{Andesite-dacite-rhyolite magmatic system}

Andesites are the most dominant volcanic rocks within the Vedlozero-Segozero GSB. The most common rocks are massive, amygdaloidal, porphyritic, brecciated, pillow lavas together with agglomerate and pelitic tuffs (Figure 2e \& 2f). The andesite lava flows vary in thickness from $1-25 \mathrm{~m}$ and are interbedded with tuffs and lava breccia formed the rock sequence with the thickness of $300-2000 \mathrm{~m}$. The time of andesite rock formation from the Hautavaara domain was determined by U-Pb (SHRIMP II) dating of zircons from andesite as 3.05-2.92Ga. The age of andesite from the Koikary, Semch, and Hautavaara domains based on U-Pb (SHRIMP II) dating of zircons from dacite lavas and dykes, is $2.90-2.84 \mathrm{Ga}$. The probable age of andesite from the Maselga area of Hautavaara domain is estimates as 2.79-2.74 using U-Pb (SHRIMP II) dating of single zircons from andesitic tuffs formed coeval with sanukitoids of the same age [17]. These results argue strongly to multi-stage model of BADR formation as in the case of mafic magmatic systems. The andesites comprise of the following series:

Adakite series (HSA and LSA): In the volcanic and subvolcanic rocks of this type the $\mathrm{SiO}_{2}$ content varies from 53 to 
76wt.\%, so they can be identified as High Silica (HSA) and Low-Silica (LSA) varieties. The first one is dominant in the series. The rocks are characterized by $\mathrm{Na}_{2} \mathrm{O}$ content ca. 2.5-5.6wt.\%, $\mathrm{MgO}<4$ wt.\%, $200<\mathrm{Sr}<100 \mathrm{ppm}, \mathrm{Ba}>350 \mathrm{ppm}, \mathrm{Zr}$ ca. $115-140 \mathrm{ppm}, \mathrm{U}$ ca. 1.1$1.7 \mathrm{ppm}$ and $\mathrm{Sr} / \mathrm{Y}=20-123$. They have depleted HREE patterns and pronounced negative anomalies of the $\mathrm{Nb}$ and $\mathrm{Ti}$.

Nb-enriched series (BADR): Regarding composition of $\mathrm{SiO}_{2}$ and alkali, the rocks are identified as andesitic basalts and rhyolites with normal alkalinity. The $\mathrm{K}_{2} \mathrm{O} / \mathrm{Na}_{2} \mathrm{O}$ varies from 0.3 to $0.5 \mathrm{wt}$. $\%$. The BADR type rocks have evaluated content of $\mathrm{Al}_{2} \mathrm{O}_{3}$ (ca. 16-18 wt.\%), Cr (20-200ppm), Ni (12-140ppm), Nb (7-11ppm), and are characterized by Zr/Y=5.4-8.8, (La/Yb) pm=8-19, and Nb/Ta=8-19. They have enriched LREE patterns with weakly fractionated HREE.

High $\mathrm{Nb}$ basalts, andesite basalts and andesite (HNB): This type is distinguished by the abnormally high $\mathrm{Nb}$ content in the andesite rocks. The HNB rocks are characterized by low-Mg number $\left(\mathrm{Mg} \#=100 * \mathrm{MgO} /\left(\mathrm{MgO}^{2}+\mathrm{FeO}_{\text {tot }}\right) \mathrm{Mg \#}=45-52\right.$ and low $\mathrm{SiO}_{2}$ content (50-53wt.\%) at moderate concentration of $\mathrm{Cr}(100-200 \mathrm{ppm})$ and Ni (30-80ppm). They have high Nb (20-45ppm) and LREE (10$26 \mathrm{ppm}$ ) concentrations and are characterized by the ratios $\mathrm{Zr} /$ $\mathrm{Y}=4.8-5.6,(\mathrm{La} / \mathrm{Yb})_{\mathrm{pm}}=4.9-6.2$, and $\mathrm{Nb} / \mathrm{Ta}=18-23$.

High Mg andesite basalts and andesite (High-Mg-BADR): This are distinguished on the base of composition similarity to the Phanerozoic reference pattern of Mg-high andesite from Baja California, Mexico [18]. The principal difference from the above mentioned rock series is the high Mg-number (Mg\#=53-64) with $\mathrm{SiO}_{2}$ content ca. 53-64wt.\%. These rocks have high $\mathrm{Cr}(220$ 620ppm) and $\mathrm{Ni}(150-650 \mathrm{ppm})$ content at low Nb content (6$9 \mathrm{ppm})$. They are characterized by $\mathrm{Zr} / \mathrm{Y}-3.5-5.9,(\mathrm{La} / \mathrm{Yb})_{\mathrm{pm}}=1.9-4.5$ and $\mathrm{Nb} / \mathrm{Ta}=17-19$ ratios.

Tholeiitic andesites (TA): This are represented by lava and dyke facies. They have from low to moderate - Mg number

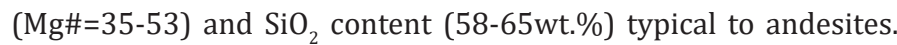
The tholeiitic andesites are enriched in $\mathrm{Cr}(270-800 \mathrm{ppm})$ and $\mathrm{Ni}(100-300 \mathrm{ppm})$ at low $\mathrm{Nb}(<4 \mathrm{ppm})$ concentration. They are characterized by $\mathrm{Zr} / \mathrm{Y}=5.0-7.5,(\mathrm{La} / \mathrm{Yb})_{\mathrm{pm}}=0.9-1.9$ and $\mathrm{Nb} / \mathrm{Ta}=12-$ 26 ratios. The distinctive feature of the tholeiitic andesites is weakly fractionated REE pattern.

It is noteworthy that the identified volcanic rock series have their intrusive analogues occurred as subvolcanic bodies and dyke systems of various scale. Sedimentary assemblage within the Vedlozero-Segozero GSB are represented by psammitic andesite tuffs, tuffites, silica tuffites, siltstones, quartz arenites, the terrigenous components of which reflect the local removal provenance.

\section{Discussion and Main Conclusion}

Petrologic and geochemical studies of the magmatic systems and the calculation of model formation conditions supposed that the formation of the komatiitic melts with the maximum $\mathrm{MgO}$ content ca. 25-30wt.\% is the consequence of high degree partial melting of mantle lherzolite at temperatures near 1750 to 1820 ${ }^{\circ} \mathrm{C}$ and pressures near 5 to $7 \mathrm{Gpa}$, associated with the formation of olivine-orthopyroxene restite phases, caused by the rising of thermal plume. The discontinuity of the initial melt compositions, obtained during the komatiite-basalt forming reactions, depends on the mineral composition of the restite phases, appeared during melting, and further magma fractionation. The formation of $\mathrm{Mg}$ high assemblages probably took place in back-arc basins. The backarc basin environments are indicated by the eruption conditions, types of sediments and the appearance of IAT-type basalts at the top of the sequence. This process is multi-stage including the oceanic stage with the formation of AUDK-UC+KB+MORB rocks, convergent stage associated with formation of AUDK-C rocks and back-arc basin closing with the IAT-type rock formation.

The initial formation of andesite magmatic systems, which are also characterized by geochemical heterogeneity, was almost synchronous with the formation of mafic magmatic systems. The observed typical assemblage comprises adakites (HSA and LSA) and Nb-rich andesite (High-Nb BARD), Mg-rich andesites (HNB) and in some cases tholeiitic andesites (TA) is the signature of their subduction origin. Besides, it is the adakites that indicated the direct melting of the subducted plate. Model calculations show, that the observed compositions of adakites (HSA and LSA) can be formed during melting of the $10-15 \%$ amphibolite, resulting in the formation of restite phase composed of $\mathrm{Cpx}(60 \%)+\mathrm{Gar}$ $(10 \%)+\mathrm{Pl}(25 \%)+\mathrm{Hbl}(5 \%)$. The further melt evolution developed in the processes of $\mathrm{Pl}+\mathrm{Cpx}$ fractionation. The other andesite rock series (HNB, High-Nb BARD, TA) formed during the processes of metasomatic mantle wedge melting and assimilation of initial adakite melts with the mantle melts.

The results obtained by using the «triad» approach, based on the analysis of the volcanic rocks, combined with intrusive and sedimentary rocks, maintain the model of the initial stage of the assembling of the Karelian Craton, corresponding to the evolution of consistent convergent system. Chronological scheme of the system evolution (Figure 3) was established using the U-Pb (SHRIMP II) dating of zircon from the representative volcanic and intrusive rocks and sediments from the Vedlozero-Segozero GSB. A chronological evolution scheme of the region is described by a sequence of events at the Paleoarchean block margin, represented by TTG (3.2-3.1Ga):

A. The formation of an initial subduction-accretion system (3.05-2.94Ga) and the simultaneous formation of mafic series in back-arc basins;

B. A collision stage with the obduction of oceanic plates on a continental basement (2.94-2.90Ga);

C. The evolution of a volcanic belt and a collision stage with the formation of sanukitoids, intermediate-felsic volcanic and granitoids $(2.88-2.84 \mathrm{Ga})$;

D. The formation of pull-apart basins (2.64-2.61Ga). 


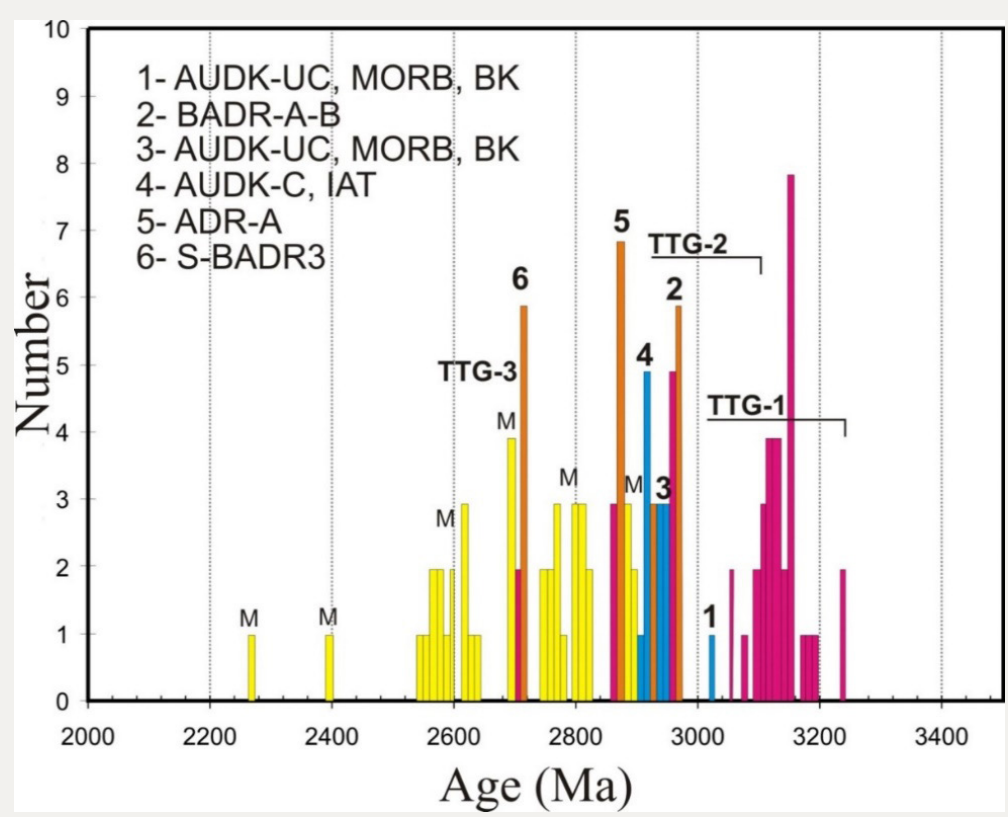

Figure 3: Distribution 207Pb/206Pb ages for zircons (SHRIMP-II) of andesitic to dacitic volcanic and sediments in area of the western framing of the Vodlozero Block with considering TTG-type. The columns show the expected time ranges for the development of magmatic systems.

AUDK: Al Undepleted Komatiites; UC: Uncontaminated Komatiites; C: Contaminated Komatiites; BADR: Basalt-Andesite-DaciteRhyolite type; A: Adakite; B: Bajaite; MORB: Mid Ocean Ridge Basalt; BK: Basaltic Komatiite; IAT: Island Arc Tholeiite; ADR: Andesite-Dacite-Rhyolite; HAS: High Silica Adakite; LSA: Low Silica Adakite; S: Sanukitoid; M: Metamorphic Processes Marked by Zircon Populations of Metamorphic Genesis

Thus, the mafic and andesite magmatic systems at the western flank of the Vodlozero Block were forming in several cycles throughout $0.40-0.45 \mathrm{Ga}$. It reflects the interaction of plume, subduction, accretion and collision processes. Concluding the results, we note as well that the key magmatic systems including the komatiite-basalt and andesite ones play an important role in the Archean crust-forming processes, particularly in the accretion collision processes. The mafic rocks formed large allochthon complexes on the continental margin that resulted in the increasing of the continental crust thickness. Subduction of separate plates caused the formation of adakite and bajaitic assemblages during its melting and BADR and TTG complexes in the processes of mixing with mantle wedge.

The conclusions of the study indicate that the assembling of Archean cratons, including Canadian, Australian, Karelian and Indian cratons, probably, was controlled by the similar factors with the key role of interaction between the mantle plumes and subduction processes, which determined not only the composition, but also the architecture of ancient continental crust.

\section{Acknowledgement}

This study was supported by grants Russian Foundation for Basic Research 16-35-00268 and 17-55-45005. We are highly thanks for DST (INT/RUS/RFBR/P-279) grants for financial support. This work is support by MOU between Bundelkhand University and Institute of Geology, Karelian Research Centre, RAS, Petrozavodsk, Russia.

\section{References}

1. Puchtel I, Hofmann A, Amelin Y, Garbe Schönberg CD, Samsonov A, et al (1999) Combined mantle plume-island arc model for the formation of the 2.9Ga sumozero kenozero greenstone belt, SE Baltic shield: Isotope and trace element constraints. Geochimica et Cosmochimica Acta 63(21): 3579-3595.

2. Polat A, Kerrich R (2001) Magnesian andesites, Nb-enriched basaltandesites, and adakites from late-Archean 2.7Ga Wawa greenstone belts, Superior Province, Canada: Implications for late Archean subduction zone petrogenetic processes. Contributions to Mineralogy and Petrology 141(1): 36-52.

3. Furnes H, Dilek Y, de Wit M (2015) Precambrian greenstone sequences represent different ophiolite types. Gondwana Research. 27(2): 649685.

4. Grove TL, Parman SW (2004) Thermal evolution of the Earth as recorded by komatiites. Earth and Planetary Science Letters 219: 173-187.

5. Kerrich R, Polat A (2006) Archean greenstone-tonalite duality: Thermochemical mantle convection models or plate tectonics in the early Earth global dynamics? Tectonophysics 415(1-4): 141-165.

6. Arndt NT, Lesher CM, Barnes SJ (2008) Komatiite. Cambridge University Press, USA, p. 467.

7. Mole DR, Fiorentini ML, Thebaud N, Cassidy KF, McCuaig TC, et al. (2014) Archean komatiite volcanism controlled by the evolution of early continents. PNAS, 111(28): 10083-10088.

8. Svetov SA (2005) Archean igneous systems in the ocean-continent transition zone in the eastern Fennoscandian Shield: Petrozavodsk. Karelian Research Centre of RAS, Russia, p. 230.

9. Arestova NA, Chekulaev VP, Lobach Zhuchenko SB, Kucherovskii GA (2015) Formation of the Archean crust of the ancient Vodlozero domain (Baltic shield). Stratigraphy and geological correlation 23(2): 119-130. 
10. Svetov SA, Svetova AI, Huhma H (2001) Geochemistry of the komatiitetholeiite rock association in the Vedlozero-Segozero Archean greenstone belt, Central Karelia. Geochem International 39(1): S24-S38.

11. Slabunov AI, Lobach Zhuchenko SB, Bibikova EV, Sorjonen Ward P, Balagansky VV, et al. (2006) The Archaean nucleus of the Fennoscandian (Baltic) Shield. In: Gee DG, Stephenson RA (Eds.), European Lithosphere Dynamics. Geological Society London Memoirs 32: 627-644.

12. Svetov SA, Stepanova AV, Chazhengina S Yu (2015) Precision (ICP-MS, LA-ICP-MS) analysis of chemical composition of rocks and minerals: Technique and assessment of result accuracy by the example of the Early Precambrian mafic complexes 7: 173-192.

13. Larionov AN, Andreichev VA, Gee DG (2004) The Vendian alkaline igneous suite of northern Timan: Ion microprobe $\mathrm{U}-\mathrm{Pb}$ zircon ages of gabbros and syenite. Geol Soc London Mem 30: 69-74.

14. Williams H, Hoffman PF, Lewry JF, James WHM, Rivers T (1991) Anatomy of North America: Thematic geologic portrayals of the continents. Tectonophysics 187(1-3): 117-134.
15. Robertson A (2002) Overview of the genesis and emplacement of mesozoic ophiolites in the eastern Mediterranean Tethyan region. Lithos 65(1-2): 1-67.

16. Kusky TM (2004) Precambrian ophiolites and related rocks. In: Kusky TM (Ed.), Developments in Precambrian Geology, Elsevier Science, USA, 13: 772 .

17. Lobach Zhuchenko SB, Chekulaev VP, Arestova NA, Levsky LK, Kovalenko AV (2000) Archean terranes of Karelia their geological and isotopegeochemical substantiation. Geotectonics 6: 26-42.

18. Calmus T, Aguillon Robles A, Maury RC, Bellon H, Benoit M, et al. (2003) Spatial and temporal evolution of basalts and magnesian andesites ('bajaites') from Baja California, Mexico: the role of slab melts. Lithos 66(1-2): 77-105.
Creative Commons Attribution 4.0 International License

For possible submissions Click Here

\section{Submit Article}

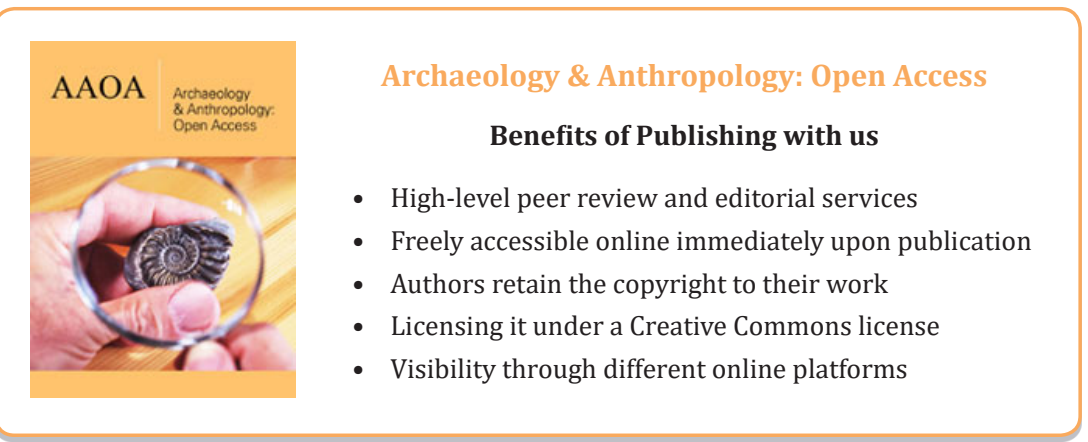

